Article

\title{
Impact of a $25 \%$ Salt Reduction on the Microbial Load, Texture, and Sensory Attributes of a Traditional Dry-Cured Sausage
}

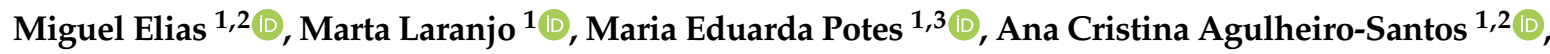 \\ Maria José Fernandes ${ }^{4}$, Raquel Garcia ${ }^{1,2} \mathbb{D}$ and Maria João Fraqueza ${ }^{4, * \mathbb{D}}$ \\ 1 MED-Mediterranean Institute for Agriculture, Environment and Development, IIFA-Instituto de \\ Investigação e Formação Avançada, Universidade de Évora, Pólo da Mitra, Ap. 94, 7006-554 Évora, Portugal; \\ elias@uevora.pt (M.E.); mlaranjo@uevora.pt (M.L.); mep@uevora.pt (M.E.P.); acsantos@uevora.pt (A.C.A.-S.); \\ raquelg@uevora.pt (R.G.) \\ 2 Departamento de Fitotecnia, Escola de Ciências e Tecnologia, Universidade de Évora, Pólo da Mitra, Ap. 94, \\ 7006-554 Évora, Portugal \\ 3 Departamento de Medicina Veterinária, Escola de Ciências e Tecnologia, Universidade de Évora, \\ Pólo da Mitra, Ap. 94, 7006-554 Évora, Portugal \\ 4 CIISA-Centro de Investigação Interdisciplinar em Sanidade Animal, Faculdade de Medicina Veterinária, \\ Universidade de Lisboa, Avenida da Universidade Técnica, 1300-477 Lisboa, Portugal; \\ mjfernandes@fmv.ulisboa.pt \\ * Correspondence: mjoaofraqueza@fmv.ulisboa.pt
}

Received: 29 March 2020; Accepted: 15 April 2020; Published: 1 May 2020

\begin{abstract}
Catalão is a Portuguese dry-cured traditional sausage, highly appreciated for its distinctive sensory properties. The aim of this study was to evaluate the impact of a $25 \%$ salt reduction on Catalão manufactured with either purebred Alentejano (Al) or crossbred Iberian $\times$ Duroc (IDr) pork meat, on its physicochemical and microbiological stability, texture parameters, and sensory attributes. No significant effect of salt reduction or genotype was observed for $\mathrm{pH}, \mathrm{a}_{\mathrm{W}}$, and microbiological parameters. PUFA content was significantly higher for Al Catalão, particularly due to the content in linoleic and linolenic fatty acids. IDr 3\% NaCl samples had the highest mean n6/n3 PUFA ratio, and the highest mean values for the atherogenicity and thrombogenicity indices, showing that both genotype and salt content influence these nutritional indices. Texture profile of Catalão was significantly influenced by salt content and genotype. Al samples were less adhesive, cohesive, and easier to chew. Low-salt Catalão was harder, more adhesive, and less cohesive, with lower resilience and higher chewiness values. Regarding sensory attributes, salt content influenced the product aroma, with reduced-salt sausages being evaluated as significantly less aromatic. Overall, a $25 \%$ salt reduction did not have a significant impact on the quality, stability, and sensory evaluation of Catalão.
\end{abstract}

Keywords: meat sausages; Catalão; low salt; pig breed; quality; safety; fatty acids profile

\section{Introduction}

Traditional cured meat products are appreciated worldwide because of their sensory characteristics. These sensory characteristics are related to meat selection, recipe, and processing of sausages among other factors [1]. In the meat selection for high quality sausages, meat from indigenous pig breeds raised under extensive or semi-extensive conditions is chosen for their more suitable color, their interspersed and infiltrated fat between the muscular fiber (intramuscular fat, marbling), and their firmer texture [2]. Moreover, autochthonous pig breeds are often fed with local products as is the case with the acorn-finished pigs, which provides unique characteristics to the meat, and particularly to the fat $[2,3]$. 
Traditional dry-cured meat sausages have been considered delicatessen products, but have lately been regarded as potentially unhealthy foods for several consumers, due to nutritional characters, associated to their high fat and salt contents [4-6]. High salt content in foods has been referred as a health factor risk for human inducing high blood pressure and cardiovascular diseases $[7,8]$. The reduction of salt on cured meat products is a task requested to the meat industry by inputs given by human health organizations and other related institutions (World Health Organization -WHO, Pan American Health Organization-PAHO, European Centre for Disease Prevention and Control-ECDC). The World Health Organization (WHO) has supported the implementation of national salt reduction strategies over the last two decades [9]. For several food products, the goal should be a reduction of at least $25 \%$ in salt content, considering their usual average. However, the perception of salt by consumers could have an impact on their preferences, because food products perceived as unsalted or very low in salt could be depreciated. Meat products are complex products, in which each ingredient plays a specific role, making their reformulation a challenging task [1]. The impact of salt reduction in the curing process of sausages depends on each product, with its indigenous fermentative microbiota, and could influence the microbial ecosystem with deviation of sensory attributes, including texture, and on the edge resulting in spoilage or unsafe products.

The production of low-salt, dry-cured meat sausages must assure not only safe and stable products, but also that consumers' appreciation will be not affected. Previous studies on Catalão sausages [10] had already suggested that salt content could be reduced to $3 \% \mathrm{NaCl}$ in the final product, with the consequent health-related advantages. Furthermore, those authors also reported that salt content had the greatest impact on the studied parameters, compared to genotype [10].

The aim of the current work was to evaluate the impact of a $25 \%$ salt reduction on Catalão, a dry-cured meat traditional sausage produced with either purebred or crossbred Iberian pork meat, on its stability (physicochemical and microbiological) and texture, as well as on its sensory attributes.

\section{Materials and Methods}

\subsection{Processing and Sampling of a Cured Meat Sausage}

Catalão, a cured traditional meat sausage was manufactured in a local factory of the Alentejo region (Portugal) with two different meat raw materials, either Alentejano purebred (Al) or crossbred Iberian $\times$ Duroc (IDr) pork meat.

Meat was manually cut into large pieces, mechanically minced $(5.0 \times 5.0 \mathrm{~mm})$, and mixed with $5 \%$ minced backfat $(5.0 \times 5.0 \mathrm{~mm})$, white wine $(3.50 \%)$, sodium chloride $(\mathrm{NaCl})$, black pepper (Piper nigrum L.) $(0.15 \%)$, white pepper $(0.15 \%)$, cumin (Cuminum cyminum L.) $(0.10 \%)$, disodium diphosphate $(0.04 \%)$, pentasodium triphosphate $(0.04 \%), \mathrm{NaNO}_{3}(0.003 \%)$, and $\mathrm{KNO}_{2}(0.003 \%)$. Nitrates and nitrites were added in the form of the commercial additive NITROS 5/5 (Formulab, Portugal). Regarding salt content, Catalão sausages were manufactured with the commercial formulation usually ( $4 \%$ salt in the final product) and with a $25 \%$ salt reduction ( $3 \%$ in the final product). Therefore, four different groups of sausages were produced: $\mathrm{Al} 3 \% \mathrm{NaCl}, \mathrm{Al} 4 \% \mathrm{NaCl}, \mathrm{IDr} 3 \% \mathrm{NaCl}$, and IDr $4 \% \mathrm{NaCl}$.

After two days under refrigeration at $5{ }^{\circ} \mathrm{C}$ and $90 \%$ relative humidity, for ripening purposes, the meat batters were stuffed into cleaned and desalted natural pork casings, with $36-38 \mathrm{~mm}$. Catalão sausages weight around $150 \mathrm{~g}$ (final product) with a horseshoe shape.

The general curing procedure of meat sausages occurred in two steps: smoking and drying. The sausages were indirectly exposed to smoke generated by burning oak (Quercus ilex L.) wood, for two days, approximately $7 \mathrm{~h} /$ day. The drying process took place in a controlled environment chamber $\left(7{ }^{\circ} \mathrm{C}\right.$ and $80-85 \%$ relative humidity) until a $35 \%$ weight loss was reached, which took about 18 days. Three independent production batches of Catalão were manufactured for each group, with duplicate samples (Catalão sausages) being collected after 35\% weight loss (final product). Sausages were immediately processed for physicochemical, microbiological, and sensory analyses. 


\subsection{Microbiological Analyses}

Sausages were prepared for microbial analysis according to ISO 6887-2 [11]. Microbiological analyses were performed following established ISO procedures or previously described methods: Salmonella spp. detection (ISO 6579) [12]; Listeria monocytogenes (ISO 11290-2) [13]; mesophiles (4833-1) [14]; lactic acid bacteria (LAB) (ISO 15214) [15]; staphylococci [16]; enterococci as described by Talon et al. [17]; Escherichia coli (ISO 16649-2) [18]; and molds and yeasts (ISO 21527-2) [19]. All microbiological analyses were performed in triplicate and the results were expressed in log cfu/g.

\subsection{Physicochemical Analyses}

\subsubsection{Determination of $\mathrm{pH}$ and $\mathrm{a}_{\mathrm{w}}$}

$\mathrm{pH}$ values were measured in triplicate in each homogenized sample with a $\mathrm{pH}$ meter (HI 9025; electrode FC 230B) equipped with a pH electrode (FC 230B, Hanna Instruments, USA) according to the procedures described in ISO 2917 [20]. Water activity $\left(\mathrm{a}_{\mathrm{W}}\right)$ was determined using a Rotronic Hygrometer station (Rotronic Hygroskop DT) previously calibrated at $20 \pm 1{ }^{\circ} \mathrm{C}$ with EA00-SCS, EA50-SCS and EA80-SCS Humidity Standards (Rotronic, Ettlingen, Germany).

\subsubsection{Determination of Total Chloride Content}

Total chloride content was quantified according to the Volhard method (ISO 1841-1) [21] and expressed as sodium chloride as a percentage by mass.

\subsubsection{Analysis of Fatty Acids Profile}

Each sausage was cut into pieces and grounded in a mechanical mill, lyophilized, placed in a glass flask, and stored at $4{ }^{\circ} \mathrm{C}$ until use. The extraction of fatty acids from Catalão sausages was performed using a Dionex 100 accelerated solvent extractor (ASE) (Dionex Corporation, USA) using the following extraction procedure: aliquots of approximately $300 \mathrm{mg}$ of sausages was combined with $6 \mathrm{~g}$ diatomaceous earth (Dionex Corporation, USA), and the mixture was transferred to a $34 \mathrm{~mL}$ stainless steel extraction cell fitted with two cellulose filters. Further, the extraction procedure carried out with a mixture of chloroform/methanol (60:40 (v/v) (Merck, Germany) containing $100 \mathrm{mg} \cdot \mathrm{L}^{-1}$ BHT (3,5-di-tert-butyl-4-hydroxytoluene) (Merck, Germany) as an antioxidant at $100{ }^{\circ} \mathrm{C}$ and $12.4 \mathrm{MPa}$. Two static extraction cycles were carried out for $5 \mathrm{~min}$ each. The solvent was removed under vacuum using a Vacobox B-177 (Buchi, Switzerland) equipped with a vacuum controller B-720, a rotavapor R-114 (Buchi, Switzerland) attached to a water bath B-480 afforded a crude residue. Next, crude residue was dissolved with $1 \mathrm{~mL}$ of chloroform and an aliquot of $100 \mu \mathrm{L}$ was taken into a glass tube and the solvent was removed under a stream of nitrogen. The residue obtained was saponified in methanolic $\mathrm{NaOH}$ solution $(0.5 \mathrm{~N})$ at $70{ }^{\circ} \mathrm{C}$ for $15 \mathrm{~min}$. Fatty acids were derivatized with boron-trifluoride-methanol solution (10 g BF3 $\left.\mathrm{L}^{1} \mathrm{CH}_{3} \mathrm{OH}\right)$ (Merck, Germany) in order to give fatty acids methyl esters (FAMEs) as described by Morrison and Smith [22]. FAMEs were analyzed by gas chromatography in a Hewlett Packard HP 6890 Series GC System (HP, USA) equipped with a split-splitless injector, an auto-sampler, a flame-ionization detector (FID), an Omegawax 320 fused silica capillary column (30 m, $0.32 \mathrm{~mm}$ i.d., $0.25 \mathrm{~mm}$ film thickness) (Supelco, USA), and HPChem software (2002). The chromatographic conditions were according to Laranjo et al. [23]. FAMEs were identified by comparison of their retention times with known standards (37-component FAME mix, Supelco 47885-U) chromatographed in identical gas chromatography conditions and by the determination of Kovats indices (data not shown). Relative fatty acid composition was quantified for each sample and presented as percentage weight for fatty acid composition. 


\subsubsection{Texture Profile Analysis}

Texture Profile Analysis (TPA) was performed at room temperature $\left(20 \pm 1{ }^{\circ} \mathrm{C}\right)$ on five replicates per sample using a Stable Micro System TA-Hdi (Stable Micro Systems, Godalming, England) as described previously [23-25]. Using the obtained force time curves, the resulting parameters were evaluated/calculated: hardness, adhesiveness, springiness, cohesiveness, resilience, and chewiness [26].

\subsection{Sensory Analysis}

Sensory analysis was performed at the University of Évora, Portugal, in a Sensory Test Room prepared according to the environment requirements described in ISO 8589 [23]. Selected assessors were chosen, trained, and monitored following the procedures described in ISO 8586 [27] for this specific meat product. Sample preparation and analysis were performed as described by Fraqueza et al. [28]. Each assessor evaluated a maximum of six samples per session. A Quantitative Descriptive Analysis (QDA) with 12 attributes was used [29]. All attributes ranged from 0 ("not perceived") to 100 ("maximum perception"). For the attributes "hardness" and "salt perception", 50 was considered as the optimum value of the QDA scale.

\subsection{Data Analysis}

Data analysis was performed using Statistica version 12 software (StatSoft, Inc., USA). A total of 24 Catalão sausages ( 4 groups $\times 3$ batches $\times 2$ samples) were analyzed. Data were presented as means \pm standard error deviation. Analyses of variance (ANOVA) were performed for the factors genotype and salt content.

\section{Results and Discussion}

No significant differences were observed between batches, proving that the authors effectively analyzed three independent production batches. Consequently, the factor batch was not further considered for statistical analysis, and all replicates were analyzed together. Moreover, no significant interaction was observed between the two factors, genotype and salt content, and thus, one-way ANOVAs were performed for each factor separately.

\subsection{Effect of Pig Genotype and Salt Reduction on Physicochemical and Microbial Parameters of Catalão}

Catalão cured sausages had a pH range from 5.46 to 5.60 (Table 1), independently of pig genotype or salt content. These products presented a low $\mathrm{a}_{\mathrm{W}}$, varying between 0.848 and 0.854 . These values were not influenced by the breed of raw meat in use and neither by salt content resulting from the process control of drying that achieved a loss weight of approximately $35 \%$. The content of total chlorides was significantly different in sausages formulated for salt reduction. These products in the market are usually formulated with a higher salt content of approximately $4-5 \%$. The salt reduction preconized in this study can be achieved with a stabilized product being observed that E. coli, Salmonella spp. and Listeria monocytogenes were not present. The technological microbiota achieved high counts independently of the raw meat breed used or salt content formulated. LAB and enterococci present on the final product Catalão ranged between 8.1 and $8.6 \mathrm{log} \mathrm{cfu} / \mathrm{g}$. This microbiota is involved in meat fermentation present on traditional sausages and responsible by the production of lactic acid and other metabolites (bacteriocins) implicated in the protection of the meat product [30]. Furthermore, staphylococci and yeasts achieved higher counts (5.9-7.0 and 6.5-7.7 log cfu/g, respectively) in the final product, probably because they are participating in the development of sausage sensory characteristics as referred by some authors [31-33]. 
Table 1. Influence of pig genotype and salt content $(\% \mathrm{NaCl})$ in physicochemical parameters and microbial counts of Catalão.

\begin{tabular}{ccccccc}
\hline \multirow{2}{*}{ Parameters } & \multicolumn{2}{c}{ Al } & \multicolumn{2}{c}{ IDr } & \multicolumn{2}{c}{$p$ Value } \\
\cline { 2 - 7 } & $\mathbf{3 \% ~ N a C l}$ & $\mathbf{4 \% ~ N a C l}$ & $\mathbf{3 \% ~ N a C l}$ & $\mathbf{4 \% ~ N a C l}$ & $\mathbf{G}$ & $\mathbf{S}$ \\
\hline $\mathrm{pH}$ & $5.46 \pm 0.06$ & $5.46 \pm 0.06$ & $5.54 \pm 0.04$ & $5.60 \pm 0.06$ & 0.067 & 0.586 \\
$\mathrm{a} W$ & $0.854 \pm 0.010$ & $0.862 \pm 0.009$ & $0.877 \pm 0.012$ & $0.848 \pm 0.012$ & 0.669 & 0.330 \\
Chlorides & $3.37^{\mathrm{B}} \pm 0.17$ & $3.99^{\mathrm{A}} \pm 0.17$ & $3.26^{\mathrm{B}} \pm 0.06$ & $4.11^{\mathrm{A}} \pm 0.25$ & 0.985 & $0.000^{* * *}$ \\
Mesophiles & $8.4 \pm 0.1$ & $8.5 \pm 0.1$ & $8.4 \pm 0.0$ & $8.4 \pm 0.1$ & 0.562 & 0.590 \\
Staphylococci & $6.0 \pm 0.1$ & $6.1 \pm 0.4$ & $5.9 \pm 0.1$ & $7.0 \pm 0.7$ & 0.432 & 0.177 \\
LAB & $8.5 \pm 0.1$ & $8.6 \pm 0.1$ & $8.5 \pm 0.0$ & $8.4 \pm 0.0$ & 0.185 & 0.809 \\
Enterococci & $8.3^{*} \pm .1$ & $8.1 \pm 0.3$ & $8.3 \pm 0.0$ & $8.3 \pm 0.0$ & 0.430 & 0.497 \\
Yeasts & $6.5^{\mathrm{b}} \pm 0.3$ & $6.8^{\mathrm{b}} \pm 0.2$ & $7.7^{\mathrm{a}} \pm 0.1$ & $7.4^{\mathrm{a}} \pm 0.1$ & $0.003^{* *}$ & 0.967
\end{tabular}

Data are represented as mean \pm standard error of the mean (SEM). Microbial counts are expressed as log cfu/g. $\mathrm{Al}$ - purebred Alentejano pig; IDr—commercial Iberian $\times$ Duroc crossbred pig. G—genotype; S—salt content; LAB-lactic acid bacteria. Significance: ${ }^{* *} p<0.01,{ }^{* * *} p<0.001$. In each row: different small letters represent significantly different means for genotype factor (Tukey's HSD test); different capital letters represent significantly different means for salt content (Tukey's HSD test).

\subsection{Effect of Pig Genotype and Salt Reduction on the Fatty Acids Profile of Catalão}

The composition of fatty acids methyl esters of Catalão is summarized in Table 2.

Table 2. Influence of pig genotype in methyl ester fatty acid-derivatives profile of Catalão.

\begin{tabular}{|c|c|c|c|c|c|}
\hline \multirow{2}{*}{ Fatty Acids } & \multicolumn{2}{|c|}{ Al } & \multicolumn{2}{|c|}{ IDr } & \multirow{2}{*}{$p$ Value } \\
\hline & $3 \% \mathrm{NaCl}$ & $4 \% \mathrm{NaCl}$ & $3 \% \mathrm{NaCl}$ & $4 \% \mathrm{NaCl}$ & \\
\hline Lauric-C12:0 & $0.23 \pm 0.12$ & $0.13 \pm 0.04$ & $0.16 \pm 0.04$ & $0.35 \pm 0.13$ & 0.431 \\
\hline Myristic-C14:0 & $2.92^{\mathrm{a}} \pm 0.44$ & $3.00^{\mathrm{a}} \pm 0.07$ & $1.77^{b} \pm 0.45$ & $0.53^{b} \pm 0.01$ & $0.000^{* * *}$ \\
\hline Palmitic-C16:0 & $20.59 \pm 1.12$ & $19.11 \pm 1.36$ & $22.78 \pm 1.70$ & $22.63 \pm 1.48$ & 0.081 \\
\hline Palmitoleic-C16:1 & $2.76 \pm 0.27$ & $2.63 \pm 0.16$ & $2.57 \pm 0.18$ & $2.73 \pm 0.22$ & 0.845 \\
\hline Margaric-C17:0 & $0.30 \pm 0.02$ & $0.22 \pm 0.05$ & $0.36 \pm 0.10$ & $0.34 \pm 0.05$ & 0.182 \\
\hline Margaroleic-C17:1 & $0.27 \pm 0.02$ & $0.27 \pm 0.01$ & $0.42 \pm 0.14$ & $0.51 \pm 0.11$ & 0.063 \\
\hline Stearic-C18:0 & $9.25^{b} \pm 0.17$ & $8.51^{b} \pm 0.83$ & $11.52^{\mathrm{a}} \pm 0.84$ & $11.60^{\mathrm{a}} \pm 0.93$ & $0.007^{* *}$ \\
\hline Oleic-C18:1 & $40.61 \pm 3.79$ & $43.38 \pm 2.27$ & $41.91 \pm 3.03$ & $42.51 \pm 3.27$ & 0.948 \\
\hline Linoleic-C18:2 & $8.42^{a} \pm 0.29$ & $8.17^{\mathrm{a}} \pm 0.62$ & $5.34^{b} \pm 0.55$ & $4.63^{b} \pm 0.45$ & $0.000 * * *$ \\
\hline Linolenic-C18:3 & $0.56^{\mathrm{a}} \pm 0.09$ & $0.49^{\mathrm{a}} \pm 0.04$ & $0.27^{\mathrm{b}} \pm 0.04$ & $0.31^{b} \pm 0.05$ & $0.004^{* *}$ \\
\hline Gadoleic-C20:1 & $0.87 \pm 0.39$ & $1.34 \pm 0.07$ & $0.85 \pm 0.09$ & $0.67 \pm 0.34$ & 0.226 \\
\hline Heneicosanoic-C21:1 & $0.60 \pm 0.50$ & $0.14 \pm 0.04$ & $0.06 \pm 0.03$ & $0.39 \pm 0.39$ & 0.656 \\
\hline
\end{tabular}

Data are represented as mean \pm standard error of the mean (SEM). Fatty acids are expressed in percentage (\%). $\mathrm{Al}$ - purebred Alentejano pig; IDr—commercial Iberian $\times$ Duroc crossbred pig. Significance: ${ }^{* *} p<0.01,{ }^{* * *} p<0.001$. In each row: different small letters represent significantly different means for genotype factor (Tukey's HSD test).

As observed in Table 2, the major fatty acids present in Catalão sausages were oleic (C18:1), palmitic (C16:0), stearic (C18:0), and linoleic (C18:2) acid (Table 2), in decreasing concentration levels, which agrees with the results of other authors [23,34]. Oleic acid is the most abundant component of the lipid fraction $[34,35]$ and it does not show any significant changes with genotype (Table 1). However, the low values obtained for sausages manufactured with Alentejano pork meat are probably due to feeding reasons $[3,34]$. Catalão sausages manufactured with Alentejano pig meat had significantly higher contents of PUFA linoleic (C18:2) and linolenic (C18:3) acids $(p<0.05)$, essential fatty acids for human health, that must be provided by the diet, because they cannot be synthesized by humans [36].

Salt content did not have any influence on the fatty acid profile of Catalão sausages (Table 2).

SFA contents ranged between $30.97 \%$ and $36.59 \%$ and MUFA concentrations were between $45.11 \%$ and $47.76 \%$ (Table 2), with no significant differences between genotypes or salt concentrations. The content in PUFA was significantly higher $(p<0.001)$ for Catalão sausages made with Alentejano (Al) raw meat (8.66-8.97\%), particularly due to the content of linoleic (C18:2) and linolenic (C18:3) fatty acids (Figure 1). 


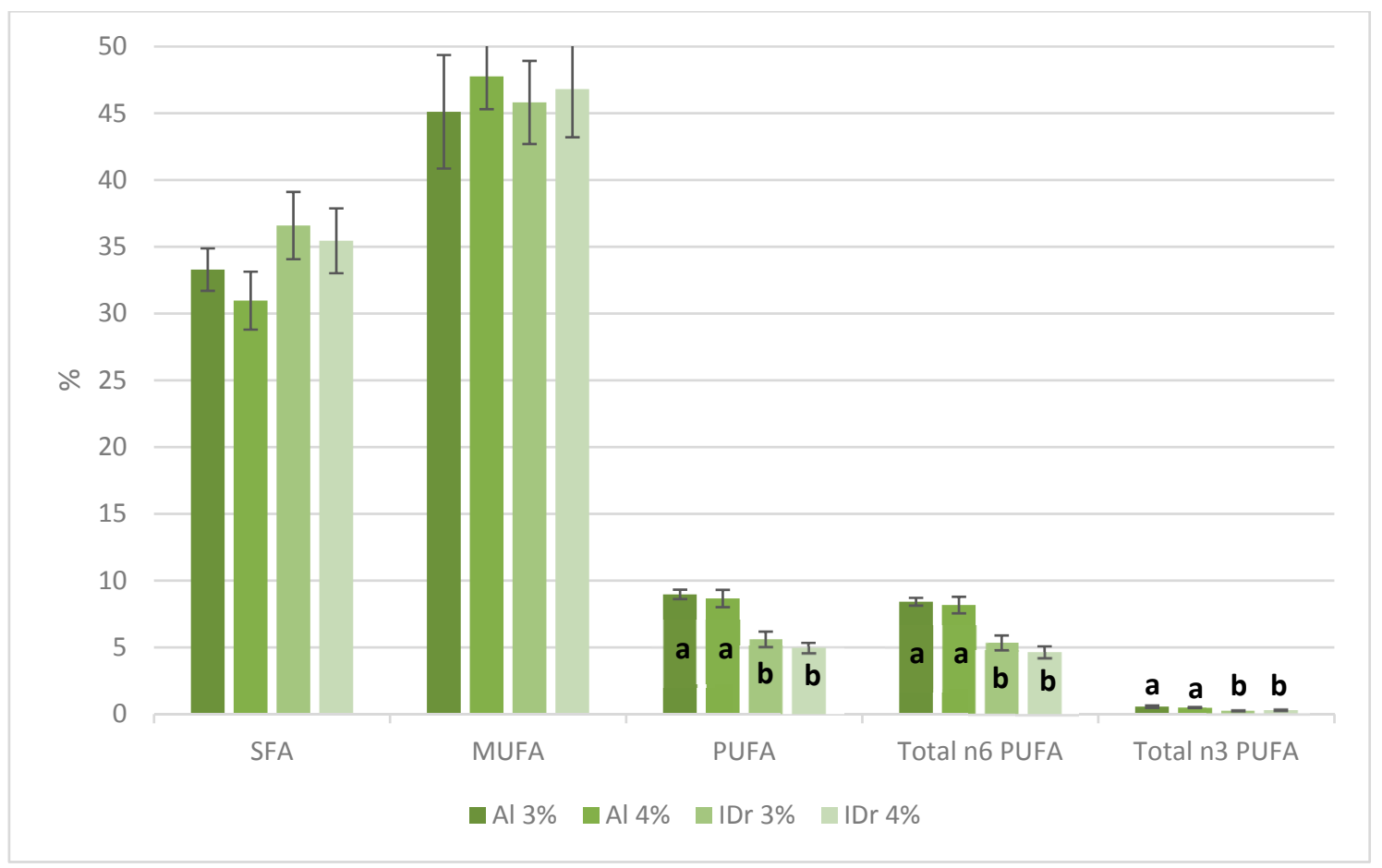

Figure 1. Catalão methyl ester fatty acid-derivatives (expressed in \%), with PUFA content showing significant differences regarding genotype.

Based on the results obtained from the FAMEs profile of Catalão, the n6/n3 PUFA ratio and some nutritional indices, namely the atherogenicity (AI) and the thrombogenicity (TI) indices, were also calculated according to Larqué and co-workers [37]. According to the literature, it is assumed that these two health-related lipid indices are the strongest markers in predicting some diseases, like cardiovascular diseases. Results are listed in Table 3.

Table 3. Nutritional indices for Catalão samples according to genotype and salt content.

\begin{tabular}{ccccccc}
\hline \multirow{2}{*}{ Indices } & \multicolumn{2}{c}{ Al } & \multicolumn{2}{c}{ IDr } & \multicolumn{2}{c}{ Value } \\
\cline { 2 - 7 } & $\mathbf{3 \% ~ N a C l}$ & $\mathbf{4} \% \mathbf{~ N a C l}$ & $\mathbf{3} \mathbf{~ N a C l}$ & $\mathbf{4} \mathbf{~ N a C l}$ & $\mathbf{G}$ & 0.522 \\
\hline n6/n3 PUFA ratio & $15.86 \pm 2.19$ & $16.85 \pm 0.40$ & $20.25 \pm 2.48$ & $16.21 \pm 4.51$ & 0.601 \\
\hline $\mathrm{AI}$ & $0.77^{\mathrm{AB}} \pm 0.01$ & $0.70^{\mathrm{B}} \pm 0.01$ & $0.81^{\mathrm{A}} \pm 0.03$ & $0.70^{\mathrm{B}} \pm 0.01$ & 0.339 & $0.002^{* *}$ \\
\hline $\mathrm{TI}$ & $0.71^{\mathrm{bA}} \pm 0.02$ & $0.62^{\mathrm{bB}} \pm 0.02$ & $0.79^{\mathrm{aA}} \pm 0.01$ & $0.76^{\mathrm{aB}} \pm 0.01$ & $0.000^{* * *}$ & $0.007^{* *}$ \\
\hline
\end{tabular}

\footnotetext{
Values are represented as mean \pm standard error of the mean (SEM). Significance: ${ }^{* *} p<0.01,{ }^{* * *} p<0.001$. In each row: different small letters represent significantly different means for genotype factor (Tukey's HSD test); different capital letters represent significantly different means for salt content (Tukey's HSD test). Indices are expressed in percentage $(\%)$. Atherogenicity Index: $\mathrm{AI}=[(4 \times \mathrm{C} 14: 0+\mathrm{C} 16: 0)+\mathrm{C} 18: 0] /\left[\sum\right.$ MUFA $+\sum$ PUFA-n6 $+\sum$ PUFA-n3]; Thrombogenicity Index: TI $=(\mathrm{C} 14: 0+\mathrm{C} 16: 0+\mathrm{C} 18: 0) /\left[\left(0.5 \times \mathrm{C} 18: 1+0.5 \times \sum\right.\right.$ MUFA +0.5 n6PUFA $+3 \times$ n3PUFA + (n3PUFA/n6PUFA)] [37]
}

Concerning n6/n3 PUFA ratios, high values were obtained (14.94-19.78), since the recommended n6/n3 PUFA ratio should not exceed a value of 4 [38]. Scientific evidence suggests that a very high n6/n3 PUFA ratio promotes the pathogenesis of many diseases, including cardiovascular diseases, cancer, and inflammatory and autoimmune diseases [38].

The Atherogenicity Index (AI) expresses the relationship between the sum of the main SFA (pro-atherogenic) and that of the main MUFA and PUFA (anti-atherogenic) [39]. The AI varies from 0.70 to 0.80 for the Catalão samples studied in this work, these values being very similar to other AI reported for fermented sausages made of pork meat from various breeds [40]. 
The Thrombogenicity Index (TI) can be defined as the ratio between the pro-thrombogenic SFA and the anti-thrombogenic MUFA and PUFA [39]. Regarding TI, the calculated values were lower than others reported in the literature [38]. Overall, IDr $3 \% \mathrm{NaCl}$ samples showed the highest mean values for all three indices. The genotype seems to have an influence on TI $(p<0.001)$. On the other hand, $\mathrm{AI}$ and TI show higher values for lower salt concentrations $(p<0.05)$.

The values obtained for both AI and TI are generally low, when compared to the literature $[39,41,42]$. In fact, olive oil, which is rich in MUFA, mainly oleic acid (C18:1), has values of 0.14 and 0.32 for AI and TI, respectively [39]. In the same study, values of $0.58-0.69$ and $1.35-1.66$, respectively for AI and TI, were reported for pork lean and fatty meat and meat sausages [39].

Despite of the significant differences observed for Atherogenicity and Thrombogenicity Indices associated to an increased salt content, the relative abundances of SFA and MUFA do not show significant differences with salt content $(p>0.05)$. Therefore, no major differences were found in the fatty acids profile regarding salt content, that may justify the differences depicted in these indices.

\subsection{Effect of Pig Genotype and Salt Reduction on Texture and Sensory Evaluation of Catalão}

Texture profile of Catalão was significantly influenced by pig genotype, particularly the following parameters: adhesiveness $(p<0.001)$, cohesiveness $(p<0.01)$, springiness and chewiness $(p<0.05)$ (Table 4). Cured meat products made with Alentejano pig had lower adhesiveness, cohesiveness, springiness and chewiness than those made with meat from commercial Iberian $\times$ Duroc crossbreed pigs. Salt concentration also had a significant effect on the texture of Catalão $(p<0.05)$ (Table 4$)$. When salt concentration was reduced to $3 \%$, the cured meat product was harder, more adhesive, and less cohesive, giving a lower resilience and a higher chewiness. In fact, other authors reported the influence of pig genotype on cured sausage texture with Iberian $\times$ Duroc crossbreed pig sausage with higher hardness and adhesiveness due to the resistance of their muscular fibers and distribution of the fat $[23,43]$. Salt influences the solubility of meat proteins. A higher salt content leads to an increase in the soluble protein fraction, contributing to an improved binding of the meat batters, and thus to significantly higher cohesiveness values for sausages with a $4 \% \mathrm{NaCl}$ content.

Table 4. Influence of pig genotype and salt content $(\% \mathrm{NaCl})$ in the texture profile analysis of Catalão.

\begin{tabular}{|c|c|c|c|c|c|c|}
\hline \multirow{2}{*}{ Texture Parameters } & \multicolumn{2}{|c|}{ Al } & \multicolumn{2}{|c|}{ IDr } & \multicolumn{2}{|c|}{$p$ Value } \\
\hline & $3 \% \mathrm{NaCl}$ & $4 \% \mathrm{NaCl}$ & $3 \% \mathrm{NaCl}$ & $4 \% \mathrm{NaCl}$ & G & $\mathrm{S}$ \\
\hline Hardness (N) & $53.995^{\mathrm{A}} \pm 2.743$ & $35.664^{\mathrm{B}} \pm 2.777$ & $52.671^{\mathrm{A}} \pm 2.739$ & $38.501^{B} \pm 2.683$ & 0.783 & $0.000 * * *$ \\
\hline Adhesiveness $\left(\mathrm{N}^{*} \mathrm{~s}\right)$ & $-2.513^{\mathrm{bA}} \pm 0.399$ & $-1.557^{\mathrm{bB}} \pm 0.433$ & $-4.642^{\mathrm{aA}} \pm 0.490$ & $-3.306^{\mathrm{aB}} \pm 0.337$ & $0.000^{* * *}$ & $0.008^{* *}$ \\
\hline Cohesiveness & $0.537^{\mathrm{bB}} \pm 0.012$ & $0.601^{\mathrm{bA}} \pm 0.018$ & $0.578^{\mathrm{aB}} \pm 0.013$ & $0.651^{\mathrm{aA}} \pm 0.008$ & $0.001 * *$ & $0.000^{* * *}$ \\
\hline Springiness (mm) & $0.808^{b} \pm 0.020$ & $0.862^{b} \pm 0.026$ & $0.885^{a} \pm 0.021$ & $0.876^{a} \pm 0.013$ & $0.032 *$ & 0.292 \\
\hline Resilience & $0.141^{\mathrm{B}} \pm 0.006$ & $0.181^{\mathrm{A}} \pm 0.017$ & $0.138^{\mathrm{B}} \pm 0.005$ & $0.172^{\mathrm{A}} \pm 0.004$ & 0.533 & $0.000^{* * *}$ \\
\hline Chewiness $\left(\mathrm{N}^{*} \mathrm{~mm}\right)$ & $23.553^{\mathrm{bA}} \pm 1.542$ & $18.261^{\mathrm{bB}} \pm 1.491$ & $26.817^{\mathrm{aA}} \pm 1.407$ & $22.080^{a B} \pm 1.782$ & 0.027 * & $0.002^{* *}$ \\
\hline
\end{tabular}

Regarding sensory analysis, the results of different attributes evaluated by the panelists are shown in Table 5.

The main differences detected by the sensory panel in Catalão sausages (Figure 2 and Table 5) were related to the marbled aspect of this cured product, with higher values for the sausages manufactured with the commercial Iberian $\times$ Duroc crossbreed. This contradicts other authors stating that cured loins made with crossbreeds Iberian $\times$ Duroc pigs presented less marbling and lower intramuscular fat (IMF) content [43]. Regarding fibrousness, significantly higher values were reported for Alentejano sausages. 
Table 5. Influence of pig genotype and salt content in the sensory evaluation of Catalão.

\begin{tabular}{ccccccc}
\hline \multirow{2}{*}{ Sensory Attributes } & \multicolumn{2}{c}{ Al } & \multicolumn{2}{c}{ IDr } & \multicolumn{2}{c}{$p$ Value } \\
\cline { 2 - 6 } & $\mathbf{3 \% ~ N a C l}$ & $\mathbf{4} \% \mathbf{~ N a C l}$ & $\mathbf{3 \% ~ N a C l}$ & $\mathbf{4 \% ~ N a C l}$ & G & $\mathbf{S}$ \\
\hline Color intensity & $70 \pm 4$ & $71 \pm 3$ & $65 \pm 2$ & $71 \pm 2$ & 0.395 & 0.237 \\
Off colors & $1 \pm 0$ & $0 \pm 0$ & $1 \pm 0$ & $0 \pm 0$ & 0.682 & 0.066 \\
Marbled & $52^{\mathrm{b}} \pm 4$ & $56^{\mathrm{b}} \pm 4$ & $64^{\mathrm{a}} \pm 4$ & $65^{\mathrm{a}} \pm 3$ & $0.009^{* *}$ & 0.623 \\
Aroma intensity & $68^{\mathrm{B}} \pm 3$ & $73^{\mathrm{A}} \pm 3$ & $67^{\mathrm{B}} \pm 3$ & $73^{\mathrm{A}} \pm 2$ & 0.772 & $0.037^{*}$ \\
Off aromas & $1 \pm 0$ & $2 \pm 1$ & $1 \pm 0$ & $0 \pm 0$ & 0.199 & 0.305 \\
Hardness & $52 \pm 3$ & $54 \pm 3$ & $52 \pm 2$ & $46 \pm 2$ & 0.126 & 0.350 \\
Fibrousness & $40^{\mathrm{a}} \pm 5$ & $41^{\mathrm{a}} \pm 6$ & $30^{\mathrm{b}} \pm 4$ & $23^{\mathrm{b}} \pm 3$ & $0.003 * *$ & 0.561 \\
Succulence & $66 \pm 3$ & $68 \pm 3$ & $69 \pm 3$ & $72 \pm 2$ & 0.176 & 0.424 \\
Flavor intensity & $68 \pm 4$ & $71 \pm 3$ & $72 \pm 2$ & $71 \pm 3$ & 0.475 & 0.722 \\
Off flavors & $3 \pm 1$ & $1 \pm 1$ & $2 \pm 2$ & $1 \pm 1$ & 0.861 & 0.259 \\
Salt perception & $50 \pm 2$ & $55 \pm 2$ & $52 \pm 1$ & $54 \pm 3$ & 0.875 & 0.167 \\
Overall appreciation & $66 \pm 3$ & $66 \pm 4$ & $72 \pm 3$ & $67 \pm 4$ & 0.332 & 0.467 \\
\hline
\end{tabular}

Data are represented as mean \pm standard error of the mean (SEM). Al-purebred Alentejano pig breed; IDr-commercial Iberian $\times$ Duroc crossbred pig. Significance: $* p<0.05, * * p<0.01$. In each row: different small letters represent significantly different means for genotype factor (Tukey's HSD test); different capital letters represent significantly different means for salt content (Tukey's HSD test).

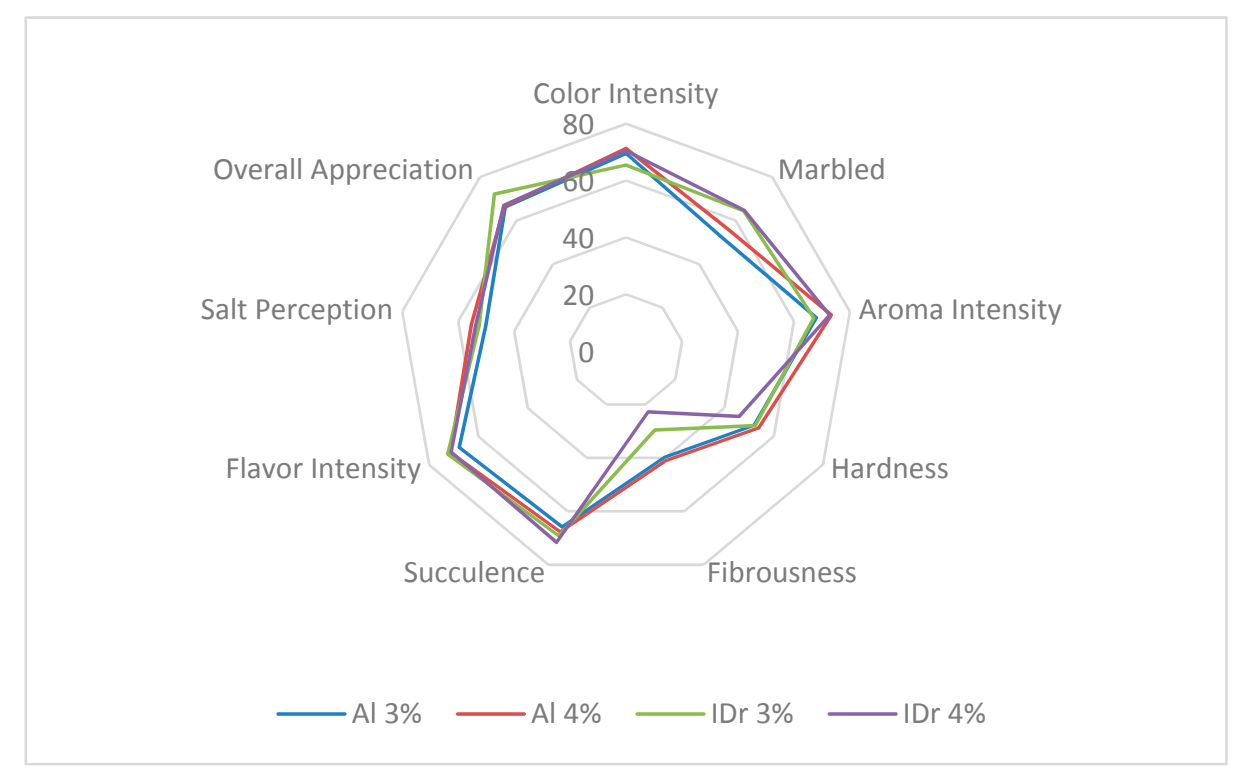

Figure 2. Graphic representation of the Catalão sensory evaluation by quantitative descriptive analysis according to genotype and salt content.

Salt content influenced the product aroma. Products with lower salt content (3\%) presented significantly lower aroma intensity $(p<0.05)$, already reported in previous studies $[10,44-46]$. Corral et al. [46] also referred that cured products with a reduction of $16 \%$ salt presented a reduction of sulphur and acid and increased aldehyde compounds.

Besides a lower aroma intensity, no other significant differences were perceived by assessors regarding reduced-salt Catalão sausages. This may be considered an advantage, because it means that the product was not unsalted or tasteless. All in all, reduced-salt Catalão sausages are stable without significant changes in the analyzed microbial groups, without a significant damage in texture or fatty acids profile. Therefore, a $25 \%$ salt reduction, with reference to the salt content of the original Catalão sausages available in the market, can be beneficial, provided that manufacturing procedures, leading to a weight loss of $35 \%$ in the final product, are observed. 


\section{Conclusions}

The effect of salt reduction and genotype on the quality and safety of dry-cured Catalão sausages was studied. Generally, a 25\% salt reduction did not have a significant impact on the stability, safety, and sensory appreciation of Catalão sausages, which thereby retained their quality.

Furthermore, no significant effect of salt reduction or genotype was observed for $\mathrm{pH}$, aw, and microbiological parameters. Regarding genotype, the content in PUFA was significantly higher for Alentejano Catalão sausages, particularly due to the content in linoleic and linolenic fatty acids. Both genotype and salt content had influence in the n6/n3 PUFA ratio, and the atherogenicity and thrombogenicity indices, with IDr $3 \% \mathrm{NaCl}$ samples showing the highest mean values for all three indices. Texture profile of Catalão was significantly influenced by salt content, with Alentejano samples being less adhesive, cohesive, and easier to chew. Low-salt Catalão sausages were harder, more adhesive, and less cohesive, with lower resilience and higher chewiness values. The texture profile of Catalão was also influenced by genotype, with significantly lower adhesiveness, cohesiveness, springiness and chewiness values for the Alentejano sausages. Regarding sensory attributes, salt content influenced aroma intensity, with reduced-salt sausages being evaluated as significantly less aromatic, which had been reported before for similar products.

Based on the presented results, and following the WHO recommendations, sausage manufacturers may be advised to safely reduce salt content, without compromising their safety and sensory attributes.

Author Contributions: Conceptualization, M.J.F. (Maria João Fraqueza), and M.L.; methodology, M.J.F. (Maria João Fraqueza), M.L., M.J.F. (Maria José Fernandes), R.G., A.C.A.-S., M.E.P.; formal analysis, R.G., A.C.A.-S., M.E.P and M.J.F. (Maria José Fernandes); investigation, M.J.F. (Maria João Fraqueza), M.L., A.C.A.-S., M.E.P.; writing-original draft preparation, M.J.F. (Maria João Fraqueza) and M.L; writing-review and editing, M.J.F. (Maria João Fraqueza), M.L., and M.E.P.; supervision, M.J.F. (Maria João Fraqueza) and M.E.; funding acquisition, M.J.F. (Maria João Fraqueza) and M.E. All authors have read and agreed to the published version of the manuscript.

Funding: This work was supported by projects PDR2020-1.0.1-FEADER-031373 and PDR2020-1.0.1-FEADER-031359, funded by national funds through Fundação para a Ciência e a Tecnologia (FCT)/MCTES and co-funded through the European Regional Development Fund (ERDF), and by projects UIDB/05183/2020 (MED) and UIDP/00276/2020 (CIISA), both financed by national funds through FCT.

Acknowledgments: M.J.F. (Maria João Fraqueza) is a member of network Red CYTED HEALTHY MEAT (119 RT0568).

Conflicts of Interest: The authors declare no conflict of interest.

\section{References}

1. Fraqueza, M.J.; Patarata, L. Fermented meat products-from the technology to the quality control. In Fermented Food Products; Sankaranarayanan, A., Amaresan, N., Dhanasekaran, D., Eds.; CRC Press: Boca Raton, FL, USA, 2020; pp. 197-237.

2. Martins, J.M.; Fialho, R.; Albuquerque, A.; Neves, J.; Freitas, A.; Nunes, J.T.; Charneca, R. Growth, blood, carcass and meat quality traits from local pig breeds and their crosses. Animal 2020, 14, 636-647. [CrossRef]

3. Martins, J.M.; Neves, J.A.; Freitas, A.; Tirapicos, J.L. Rearing system and oleic acid supplementation effect on carcass and lipid characteristics of two muscles from an obese pig breed. Animal 2015, 9, 1721-1730. [CrossRef]

4. Klurfeld, D.M. Research gaps in evaluating the relationship of meat and health. Meat Sci. 2015, 109, 86-95. [CrossRef] [PubMed]

5. Petit, G.; Jury, V.; de Lamballerie, M.; Duranton, F.; Pottier, L.; Martin, J.-L. Salt Intake from Processed Meat Products: Benefits, Risks and Evolving Practices. Compr. Rev. Food Sci. Food Saf. 2019, 18, 1453-1473. [CrossRef]

6. Muguerza, E.; Gimeno, O.; Ansorena, D.; Astiasarán, I. New formulations for healthier dry fermented sausages: A review. Trends Food Sci. Technol. 2004, 15, 452-457. [CrossRef]

7. Aburto, N.J.; Ziolkovska, A.; Hooper, L.; Elliott, P.; Cappuccio, F.P.; Meerpohl, J.J. Effect of lower sodium intake on health: Systematic review and meta-analyses. Br. Med J. 2013, 346, f1326. [CrossRef]

8. Elias, M.; Laranjo, M.; Agulheiro-Santos, A.C.; Potes, M.E. The Role of Salt on Food and Human Health. In Salt in the Earth; Çinku, M.C., Karabulut, S., Eds.; IntechOpen: London, UK, 2020. [CrossRef] 
9. Trieu, K.; Neal, B.; Hawkes, C.; Dunford, E.; Campbell, N.; Rodriguez-Fernandez, R.; Legetic, B.; McLaren, L.; Barberio, A.; Webster, J. Salt Reduction Initiatives around the World-A Systematic Review of Progress towards the Global Target. PLoS ONE 2015, 10, e0130247. [CrossRef]

10. Laranjo, M.; Gomes, A.; Agulheiro-Santos, A.C.; Potes, M.E.; Cabrita, M.J.; Garcia, R.; Rocha, J.M.; Roseiro, L.C.; Fernandes, M.J.; Fernandes, M.H.; et al. Characterisation of "Catalão" and "Salsichão" Portuguese traditional sausages with salt reduction. Meat Sci. 2016, 116, 34-42. [CrossRef]

11. ISO. Microbiology of Food and Animal Feeding Stuffs_Preparation of Test Samples, Initial Suspension and Decimal Dilutions for Microbiological Examination-Part 2: Specific Rules for the Preparation of Meat and Meat Products; ISO: Geneva, Switzerland, 2003; Volume 6887-6882.

12. ISO. Microbiology of Food and Animal Feeding Stuffs-Horizontal Method for the Detection of Salmonella spp.; ISO: Geneva, Switzerland, 2002; Volume ISO 6579.

13. ISO. Microbiology of the Food Chain-Horizontal Method for the Detection and Enumeration of Listeria monocytogenes and of Listeria spp.-Part 2: Enumeration method; ISO: Geneva, Switzerland, 2014; Volume ISO 11290-11292.

14. ISO. Microbiology of the food chain-Horizontal method for the enumeration of microorganisms-Part 1: Colony count at 30 degrees C by the pour plate technique; ISO: Geneva, Switzerland, 2013; Volume ISO 4833-4831.

15. ISO. Microbiology of Food and Animal Feeding Stuffs-Horizontal Method for the Enumeration of Mesophilic Lactic Acid Bacteria-Colony-Count Technique at $30^{\circ} \mathrm{C}$; ISO: Geneva, Switzerland, 2015; Volume ISO 15214.

16. Laranjo, M.; Gomes, A.; Agulheiro-Santos, A.C.; Potes, M.E.; Cabrita, M.J.; Garcia, R.; Rocha, J.M.; Roseiro, L.C.; Fernandes, M.J.; Fraqueza, M.J.; et al. Impact of salt reduction on biogenic amines, fatty acids, microbiota, texture and sensory profile in traditional blood dry-cured sausages. Food Chem. 2017, 218, 129-136. [CrossRef]

17. Talon, R.; Lebert, I.; Lebert, A.; Leroy, S.; Garriga, M.; Aymerich, T.; Drosinos, E.H.; Zanardi, E.; Ianieri, A.; Fraqueza, M.J.; et al. Traditional dry fermented sausages produced in small-scale processing units in Mediterranean countries and Slovakia. 1: Microbial ecosystems of processing environments. Meat Sci. 2007, 77, 570-579. [CrossRef]

18. ISO. Microbiology of Food and Animal Feeding Stuffs-Horizontal Method for the Enumeration of Beta-GlucuronidasePositive Escherichia coli-Part 2: Colony-Count Technique at $44{ }^{\circ} \mathrm{C}$ Using 5-Bromo-4-Chloro-3-Indolyl Beta-D-Glucuronide; ISO: Geneva, Switzerland, 2012; Volume ISO 16649-2.

19. ISO. Microbiology of Food and Animal Feeding Stuffs-Horizontal Method for the Enumeration of Yeasts and Moulds_Part 2: Colony Count Technique in Products with Water Activity Less than or Equal to 0.95; ISO: Geneva, Switzerland, 2008; Volume ISO 21527-2.

20. ISO. Meat and Meat Products_Measurement of pH_Reference Method; ISO: Geneva, Switzerland, 1999; Volume 2917.

21. ISO. Meat and Meat Products-Determination of Chloride Content_Part 1: Volhard Method; ISO: Geneva, Switzerland, 1996; Volume ISO 1841-1.

22. Morrison, W.R.; Smith, L.M. Preparation of fatty acid methyl esters and dimethylacetals from lipids with boron fluoride-methanol. J. Lipid Res. 1964, 5, 600-608. [PubMed]

23. Laranjo, M.; Agulheiro-Santos, A.C.; Potes, M.E.; Cabrita, M.J.; Garcia, R.; Fraqueza, M.J.; Elias, M. Effects of genotype, salt content and calibre on quality of traditional dry-fermented sausages. Food Control 2015, 56, 119-127. [CrossRef]

24. Caine, W.R.; Aalhus, J.L.; Best, D.R.; Dugan, M.E.R.; Jeremiah, L.E. Relationship of texture profile analysis and Warner-Bratzler shear force with sensory characteristics of beef rib steaks. Meat Sci. 2003, 64, 333-339. [CrossRef]

25. Honikel, K.-O. Reference methods supported by OECD and their use in Mediterranean meat products. Food Chem. 1997, 59, 573-582. [CrossRef]

26. Agulheiro-Santos, A.C.; Roseiro, C. Physical Properties of Foods: Novel Measurement Techniques and Applications. In Rheological Properties of Foods; Taylor \& Francis Group: London, UK, 2012; pp. 23-52.

27. ISO. Sensory Analysis-General Guidelines for the Selection, Training and Monitoring of Selected Assessors and Expert Sensory Assessors; ISO 8586; ISO: Geneva, Switzerland, 2012.

28. Fraqueza, M.J.; Laranjo, M.; Alves, S.; Fernandes, M.H.; Agulheiro-Santos, A.C.; Fernandes, M.J.; Potes, M.E.; Elias, M. Dry-Cured Meat Products According to the Smoking Regime: Process Optimization to Control Polycyclic Aromatic Hydrocarbons. Foods 2020, 9, 91. [CrossRef]

29. ISO. Sensory Analysis-Methodology-General Guidance for Establishing a Sensory Profile; ISO 13299; ISO: Geneva, Switzerland, 2016.

30. Fraqueza, M.J. Antibiotic resistance of lactic acid bacteria isolated from dry-fermented sausages. Int. J. Food Microbiol. 2015, 212, 76-88. [CrossRef] 
31. Alfaia, C.M.; Gouveia, I.M.; Fernandes, M.H.; Fernandes, M.J.; Semedo-Lemsaddek, T.; Barreto, A.S.; Fraqueza, M.J. Assessment of Coagulase-Negative Staphylococci and Lactic Acid Bacteria Isolated from Portuguese Dry Fermented Sausages as Potential Starters Based on Their Biogenic Amine Profile. J. Food Sci. 2018, 83, 2544-2549. [CrossRef]

32. Fraqueza, M.J.; Rocha, J.M.; Laranjo, M.; Potes, M.E.; Fialho, A.R.; Fernandes, M.J.; Fernandes, M.H.; Barreto, A.; Semedo-Lemsaddek, T.; Elias, M. What is the Main Processing Factor Influencing Staphylococcus Species Diversity in Different Manufacturing Units? J. Food Sci. 2019, 84, 2932-2943. [CrossRef]

33. Laranjo, M.; Elias, M.; Fraqueza, M.J. The Use of Starter Cultures in Traditional Meat Products. J. Food Qual. 2017, 2017, 1-18. [CrossRef]

34. Cava, R.; Ruiz, J.; López-Bote, C.; Martin, L.; Garcia, C.; Ventanas, J.; Antequera, T. Influence of finishing diet on fatty acid profiles of intramuscular lipids, triglycerides and phospholipids in muscles of the Iberian pig. Meat Sci. 1997, 45, 263-270. [CrossRef]

35. Lopez-Bote, C.J. Sustained utilization of the Iberian pig breed. Meat Sci. 1998, 49 (Suppl. S1), S17-S27. [CrossRef]

36. Kaur, N.; Chugh, V.; Gupta, A.K. Essential fatty acids as functional components of foods-A review. J. Food Sci. Technol. 2014, 51, 2289-2303. [CrossRef] [PubMed]

37. Larqué, E.; Garaulet, M.; Pérez-Llamas, F.; Zamora, S.; Tebar, F.J. Fatty acid composition and nutritional relevance of most widely consumed margarines in Spain. Grasas y Aceites 2003, 54. [CrossRef]

38. Romero, M.C.; Romero, A.M.; Doval, M.M.; Judis, M.A. Nutritional value and fatty acid composition of some traditional Argentinean meat sausages. Food Sci. Technol. 2013, 33, 161-166. [CrossRef]

39. Ulbricht, T.L.V.; Southgate, D.A.T. Coronary heart disease: Seven dietary factors. Lancet 1991, 338, $985-992$. [CrossRef]

40. Stajić, S.; Živković, D.; Perunović, M.; Šobajić, S.; Vranić, D. Cholesterol content and atherogenicity of fermented sausages made of pork meat from various breeds. Procedia Food Sci. 2011, 1, 568-575. [CrossRef]

41. Senso, L.; Suárez, M.D.; Ruiz-Cara, T.; García-Gallego, M. On the possible effects of harvesting season and chilled storage on the fatty acid profile of the fillet of farmed gilthead sea bream (Sparus aurata). Food Chem. 2007, 101, 298-307. [CrossRef]

42. Garaffo, M.A.; Vassallo-Agius, R.; Nengas, Y.; Lembo, E.; Rando, R.; Maisano, R.; Dugo, G.; Giuffrida, D. Fatty Acids Profile, Atherogenic (IA) and Thrombogenic (IT) Health Lipid Indices, of Raw Roe of Blue Fin Tuna (Thunnus thynnus L.) and Their Salted Product “Bottarga". Food Nutr. Sci. 2011, 2, 736-743. [CrossRef]

43. Ramírez, M.R.; Cava, R. Effect of Iberian X Duroc genotype on dry-cured loin quality. Meat Sci. 2007, 76, 333-341. [CrossRef]

44. Corral, S.; Salvador, A.; Belloch, C.; Flores, M. Effect of fat and salt reduction on the sensory quality of slow fermented sausages inoculated with Debaryomyces hansenii yeast. Food Control 2014, 45, 1-7. [CrossRef]

45. Corral, S.; Salvador, A.; Belloch, C.; Flores, M. Improvement the aroma of reduced fat and salt fermented sausages by Debaromyces hansenii inoculation. Food Control 2015, 47, 526-535. [CrossRef]

46. Corral, S.; Salvador, A.; Flores, M. Salt reduction in slow fermented sausages affects the generation of aroma active compounds. Meat Sci. 2013, 93, 776-785. [CrossRef] [PubMed]

(C) 2020 by the authors. Licensee MDPI, Basel, Switzerland. This article is an open access article distributed under the terms and conditions of the Creative Commons Attribution (CC BY) license (http://creativecommons.org/licenses/by/4.0/). 